\title{
TRAVEL PLANS: A CRITICAL COMPARISON OF THE APPLICATION OF LAND USE PLANNING PROCESSES IN ENGLAND AND SCOTLAND
}

\author{
Richard Llewellyn ${ }^{1}$, Reggie Tricker ${ }^{2}$, Deborah Paton ${ }^{3}$ \\ ${ }^{1}$ Transport Research Institute, Edinburgh Napier University, United Kingdom \\ ${ }^{2}$ City of Edinburgh Council, Edinburgh, United Kingdom \\ ${ }^{3}$ AECOM, Edinburgh, United Kingdom
}

Submitted 15 October 2013; accepted 3 March 2014; first published online 9 May 2014

\begin{abstract}
A Travel Plan is a travel demand management tool which has the potential to alter the means of travel to or from any destination or origin of movement to modes of transport other than the private car. A Travel Plan typically comprises of a package of measures which interact to achieve such modal shift. Travel Plans or their equivalents have been used successfully in various parts of the world to manage travel demand. Ultimately however, the success or failure of a Travel Plan meeting its intended objectives hinges on an appropriate mechanism, usually legal, to ensure that the measures within the plan are observed and properly implemented.

Although both are constituent parts of the UK, England and Scotland operate under separate legal and governance systems. In the international context of Travel Planning, this results in the unique and novel situation of two countries of virtually identical demographics but with potentially different implementation systems. This paper investigates the differences between the two approaches adopted, making reference to best practice examples from local authorities in both countries.

Firstly, the legal position of Travel Plans is investigated through a comparison of the relevant English and Scottish legislation. Particular reference is made to the ability of such legislation to facilitate 'soft' measures and secure a long term agreement with owners or occupiers. Both of these aspects are critical to the successful enforcement of Travel Plans.
\end{abstract}

Evidence from previous research suggests that central government policy can be used as an incentive to ensure that local authorities promote and monitor Travel Plan activity associated with development. However, given the legal complexities of land use planning and the limited resources of local authorities, clear and direct national government guidance is also considered an important factor. In recognition of these facts, the paper goes on to compare and contrast the approaches to policy and guidance adopted by the two countries.

Through a combination of desktop and interview surveys, the practical application of the legal, policy and guidance aspects of travel planning in the two countries is reviewed. Using a review of local authority approaches in England and Scotland, conclusions are drawn with regard to the relevant strengths and weaknesses of approaches adopted in each country.

Previous research suggests that the implementation of single-use development Travel Plans is now widely observable across the UK, albeit with varying degrees of long-term success. However, implementation of Travel Plans across wide area, mixed use development carries with it additional challenges, both in legal and practical terms. Specific reference is made to how local authorities are able to address these issues.

The paper concludes with a discussion of these findings and makes a number of suggestions on how the processes may be improved to facilitate better application, monitoring and enforcement of Travel Plans across the UK and internationally.

Keywords: travel plans; mobility management; planning process; travel demand management; transport policy.

Reference to this paper should be made as follows: Llewellyn, R.; Tricker, R.; Paton, D. 2014. Travel plans: a critical comparison of the application of land use planning processes in England and Scotland, Transport 29(3): $235-247$. http://dx.doi.org/10.3846/16484142.2014.913260 


\section{Introduction}

\section{Background}

A Travel Plan is a travel demand management tool which has the potential to alter the means of travel to or from any destination or origin of movement to modes of transport other than the private car. A Travel Plan typically comprises of a package of measures or incentives to achieve such modal shift (Tricker 2008). Travel Plans or their equivalents have been used successfully in various parts of the world to manage travel demand.

Motivation for the adoption of Travel Plans by organisations can be considered as either externally or internally driven (Roby 2010). Externally driven adoption is usually as a result of a policy or planning consent; whereas internally driven adoption is often associated with facilities management or a company's environmental agenda. Whilst the internally driven adoption can increase over time, the use of policy and the planning system remains the main initial motivation for adoption of such measures.

Whilst Travel Plans are a well-established tool in many countries, others are in the early stages or yet to implement them. It is noted though that most developed and many developing countries are considering them in some form (Enoch 2012). Even in those countries where Travel Plans are more widely adopted, the degree of success is often mixed. The goals of policies to manage transport demand can even be contradictory to the goals promoted by other sectors, such as economic development (Hendricks 2008). Until Travel Plans reach the position of a mainstream travel demand tool in a particular country, lessons can be learnt from the implementation in other jurisdictions. This is particularly relevant for countries at the early stages of Travel Plan adoption, where policies and planning processes have not yet been developed and are most open to influence.

In many developed countries, the pressure on Travel Plans as a demand management measure is most likely to arise from managing existing levels of congestion, changes in residential preferences and population growth. However, the OECD (2013) highlights areas of the world which are predicted to grow at a substantial rate, such as China, India and Brazil. To achieve sustainable growth, and ensure that economic success is not hindered by traffic congestion, travel demand measures such as Travel Plans potentially have a significant part to play. Recent work in China (Replogle et al. 2009; Strompen et al. 2012) for example, has identified that travel demand measures such as Travel Plans will be critical to the economic success of major cities such as Beijing. However, the approach in some cities continues to be to increase road capacity, e.g. Moscow (Pushkova 2010).

It is therefore of likely benefit that such areas learn from the experience of governments and planners, such as those in England and Scotland, with a view to maximising the effectiveness of their own transport demand measures, such as Travel Plans.

\section{Travel Planning in the UK}

Although both are constituent parts of the UK, England and Scotland operate under separate legal and governance systems ${ }^{1}$ at a national and local level. Whilst the formal devolution of many central government functions in 1998 significantly changed the administration of Scotland ${ }^{2}$, even prior to this several distinctions existed. For example, since the Act of Union of 1707, which originally brought together the Kingdoms of England and Scotland together (UK Parliament 1707), Scotland has retained its own legal system, which is distinct from that of England. The concept of having different approaches between the different countries in areas such as planning is, therefore, not a new one.

This difference means the application, monitoring and enforcement of Travel Plans varies between the two countries. However, other factors which could affect the uptake of Travel Plan measures such as climate, availability and quality of alternative travel modes, disposable income and private sector support are broadly within the same range. On this basis, when looking solely at the impact that policy and legislative issues have on Travel Plans, the two countries make interesting comparators.

\section{Practice in England}

Recent work (Lewis 2009; Rye et al. 2011) reviews the effectiveness of the planning process for securing Travel Plans in England. The work found a relatively high number of Travel Plans being secured in relation to new land use developments, guided by a policy and legislative framework discussed later in this research. However, given the levels of understanding and buy-in of the development industry towards travel plans, monitoring and enforcement was still needed and cited as a particular issue. The availability of resources subsequently to monitor and enforce Travel Plans, to deal with questions over legal agreements and to address issues over local and central government leadership, is a reason echoed by many in the wider transport planning profession for Travel Plans not achieving their full potential (Enoch, Ison 2010).

\section{Practice in Scotland}

In general, whilst a reasonable amount of work has been undertaken in England, in Scotland, less has been published about the effectiveness of Travel Plans. Earlier work (Scottish Executive 2006a) suggested that aware-

\footnotetext{
${ }^{1}$ For the purposes of this paper, the term Central Government has been used to denote UK wide governance. The term 'National Government' refers generally to the Westminster government and appropriate departments and executive agencies responsible for England and the devolved Scottish Government respectively.

2 The devolved government established in Scotland 1998 was named the 'Scottish Executive'; however, in 2007 it was rebranded as the 'Scottish Government'. In this research, the title quoted is that which was applicable at the time in question, although both terms refer to the same devolved administration.
} 
ness and use of Travel Plans as a transport demand management tool was, at that time, less prevalent in Scotland than in England. However, where Travel Plans were being required by local authorities, similar issues to England in terms of enforcement and monitoring were observed.

Since the Scottish research was undertaken, several changes have taken place in terms of legislation, policy changes, and governance. A new executive agency for transport was established, Transport Scotland on 1 January 2006. The Scottish Government developed a National Transport Strategy (Scottish Executive 2006b) and subsequently new Scottish planning policy (Scottish Government 2010) and transport guidance (Transport Scotland 2012) were issued, both making reference to the promotion of Travel Plans. In addition, prior to these changes, all local authorities were invited to prepare their own Local Transport Strategies (LTS) which also formally set out their policy on Travel Plans (where these policies exist).

In Scotland, a regional tier of transport policymaking has influenced Travel Plan development and delivery. Voluntary Regional Transport Partnerships (RTPs) have existed for many years in Scotland, and were given statutory status in the Transport (Scotland) Act 2005 (Scottish Parliament 2005). Specific national funding streams for Travel Plan Officers in these RTPs gave particular momentum to the delivery of some effective Travel Plan partnerships, North East of Scotland Transport Partnership (NESTRANS) being a case in point. Whilst this allocated funding for Travel Plan Officers no longer continues, the legacy of successful partnership working on Travel Plans continues at the regional level in parts of Scotland.

Given all of these changes, it is worth revisiting the recent situation in Scotland with regard to Travel Plans; a central part of this research is a survey which aims to achieve this. The new survey work in Scotland has been combined with recent work looking at the implementation of Travel Plans in England. The findings from both countries have been compared against national government aspirations and conclusions drawn against the success of Travel Plans in practice.

\section{Approach}

The structure of this paper is as follows. The aims and methods of research are first described. This is followed by a review of the structure of the English and Scottish planning systems, along with key national legislation and guidance for the two countries. Known issues in relation to implementation of Travel Plans in both countries are then discussed. The results of the survey undertaken of Scottish local authorities are considered in relation to the changes in governance over recent years. The final part of this paper considers what lessons can be learnt from the two approaches and makes comment on the potential future of Travel Plans as a transport demand management tool in the UK and internationally.

\section{Research Aims and Methods}

\subsection{Objectives}

To further understand the effectiveness of the land use planning processes in England and Scotland with regard to Travel Plans, the research questions to be answered as part of this study are:

- What is the current comparative position of Travel Plans as a transport demand management tool in Scotland and England?

- To what degree do the different governance and legal structures in the two countries influence the success of Travel Plans?

- What is the likely future of Travel Plans in the two countries and what lessons can be learnt for adoption of Travel Plans by other nations?

\subsection{Research Methods}

The work undertaken comprised four components:

- a review of the legislative and policy frameworks for Travel Plan production in England and Scotland;

- a review of previous studies of Travel Plan uptake in England and Scotland to determine their effectiveness;

- a desktop study of published Scottish local authority Travel Plan policy;

- a survey of current practice in Scotland.

\section{Reviews of Legislation, Policy and Previous Studies}

To provide a context for the main research, a comprehensive review of the applicable legislation and policy was undertaken. The prime source of information was the current government and agencies themselves, supplemented by reference to revoked policy where relevant to the research.

The review of previous studies of Travel Plan uptake included academic journal articles, conference papers, published government research and unpublished dissertations by students of Edinburgh Napier University.

\section{Survey of Current Practice in Scotland}

The first element of research undertaken was a desktop study of Scottish local authority policy on Travel Plans. The Scottish Transport Assessment Guidance (Transport Scotland 2012) states that: 'Local Authorities should help facilitate the development of effective Travel Plans by ensuring that measures to support them are incorporated in local planning policies, including the Local Development Plan and Local Transport Strategy'.

To ascertain the current compliance with this recommendation, a web search of Local Development Plans (LDP) and Local Transport Strategies (LTS) from local authorities in Scotland was undertaken. The LDPs and LTSs were sourced from the local authority's website and extracts of the relevant clauses were summarised in tabular form for reference. It was noted from the search that many local authorities are currently in the process of renewing both of these documents; hence this review 
gave a flavour of approaches rather than a complete picture. Local authorities making reference to Travel Plans within these documents could be considered to be more advanced than others in their use of such travel demand management measures. In the case where LDPs and LTSs were being rewritten, it was clear that it would be useful to understand at least whether local authorities were intending to make a change. On this basis, questions were drafted to ascertain such intent for inclusion in the final part of the research, the online questionnaire.

To undertake this research, an online questionnaire was chosen as the preferred method of obtaining data on the provision of Travel Plans. The survey was undertaken just before the summer holiday period which can often be a busy period for officers completing work before going away. It was felt that a better response rate could be obtained with a short, easy to complete questionnaire than an in-depth telephone interview, which respondents may be reluctant to participate in given time commitments. The use of on online approach also increased the anonymity of the survey, which was con- sidered beneficial given some of the potentially politically sensitive questions on issues such as the enforcement of legal agreements.

Prior to the issue of the survey, all local authorities were contacted by telephone to provide advance notification. The telephone call was also used to ascertain the most appropriate officer to provide a response to the survey, again to ensure the best quality of returned data and to ensure availability, thus maximising the response rate.

In total, 21 questions were prepared for inclusion in the online survey. For purposes of comparability, the questions were prepared to align as closely as possible with the topics of previous research. However, given that previous work included several different studies, some summarising was needed in certain areas to ensure an effective question could be worded and that the questionnaire was kept to a reasonable size.

A mixture of open and closed questions was used for the questionnaire. The full list of questions is shown in Table 1.

Table 1. Full list of questions

\begin{tabular}{|c|c|}
\hline No. & Question \\
\hline 1 & When processing planning applications, what development types do you usually require Travel Plans for? \\
\hline 2 & $\begin{array}{l}\text { Roughly speaking, how many planning consents would you say include conditions or obligations requiring a Travel Plan } \\
\text { in your local authority area in a typical year? }\end{array}$ \\
\hline 3 & How often do you use PLANNING CONDITIONS in securing Travel Plan measures? \\
\hline 4 & How often do you use PLANNING OBLIGATIONS (e.g. Section 75) to secure Travel Plan measures? \\
\hline 5 & Any comments on current legislation in relation to Travel Plans? Does it meet your needs? \\
\hline 6 & Do you agree that current Scottish Government policy (e.g. SPP 2010) is clear on the role of Travel Plans? \\
\hline 7 & Any comments on Scottish Government policy relating to Travel Plans? \\
\hline 8 & $\begin{array}{l}\text { Do you agree that current Scottish Government guidance (e.g. Transport Scotland - Transport Assessment Guidance } \\
\text { 2012) is helpful in defining and promoting the use of Travel Plans? }\end{array}$ \\
\hline 9 & Any comments on Scottish Government guidance relating to Travel Plans? \\
\hline 10 & $\begin{array}{l}\text { The Transport Scotland - Transport Assessment Guidance published in } 2012 \text { suggests that 'Local Authorities should help } \\
\text { facilitate the development of effective Travel Plans by ensuring that measures to support them are incorporated in local } \\
\text { planning policies, including the Local Development Plan and Local Transport Strategy'. With regard to the use of Travel Plans } \\
\text { in association with developments, which of the following statements best describes each document for your Local Authority? } \\
\text { Already supports Travel Plans; planning to support Travel Plans; no intention to support Travel Plans; don't know/not sure. }\end{array}$ \\
\hline 11 & Any comments on Local Authority guidance and attitudes towards Travel Plans? \\
\hline 12 & Does your Local Authority have a full or part time nominated Travel Plan Officer? \\
\hline 13 & Does your authority monitor the implementation of ACTIONS / MEASURES in Travel Plans? \\
\hline 14 & Does your authority monitor the achievements of TARGETS/TRIP REDUCTIONS in Travel Plans? \\
\hline 15 & How long do you usually aim to monitor Travel Plans for? \\
\hline 16 & $\begin{array}{l}\text { Are you aware of any breaches in Travel Plan legal agreements in your local authority area and if so, approximately } \\
\text { how many? }\end{array}$ \\
\hline 17 & Have these breaches been remedied and if so how many? \\
\hline 18 & If enforcement has taken place, what form(s) has it taken? \\
\hline 19 & What are the main reasons for lack of enforcement? \\
\hline 20 & $\begin{array}{l}\text { Over the next few years, do you see the role for Travel Plans as a transport demand management measure: substantially } \\
\text { declining; declining; staying about the same; increasing; substantially increasing? }\end{array}$ \\
\hline 21 & $\begin{array}{l}\text { What are the three most important things that could be done to improve the effectiveness of Travel Planning } \\
\text { in Scotland? }\end{array}$ \\
\hline
\end{tabular}


The questionnaire was coded and issued using an internet based, web survey provider. Links to the survey were provided by e-mail to the contacts identified by earlier telephone contact with the local authorities. The survey was formally open for completion during a two week period, although later responses were accepted if received prior to the analysis of the data.

\section{Legislative and Policy Frameworks}

\subsection{Travel Plans in the UK}

Travel Plans in the UK first emerged in the mid-1990s. Initially adopted voluntarily by some public sector organisations, their potential as a travel demand tool was formally recognised by national government in the 1998 White Paper, A New Deal for Transport: Better for Everyone (A New Deal... 1998). The white paper was a UKwide one, although it was published in the same year as the Scotland Act 1998 (House of Commons 1998).

The Scotland Act set out the devolution of powers, including planning and transport, to the newly formed Scottish Executive (now Scottish Government), marking an opportunity for divergence of policies between Scotland and other parts of the UK. That said, the UK White Paper was quickly followed by the Scottish Integrated Transport White Paper, Travel Choices for Scotland (Scottish Executive 1998), which indicated a similar level of support for Travel Plans under devolved governmental arrangements. Policy guidance supported by relevant legislation has subsequently developed in both countries, set out in the following sections.

\subsection{England}

\section{Planning Law in England}

Planning law in England is defined by central government. The principal legislation is the Town and Country Planning Act (House of Commons 1990) and the Planning and Compulsory Purchase Act (House of Commons 2004).

Section 1 of the Town and Country Planning act defines Local Planning Authorities (LPAs) responsible for planning matters at a local government level. In England, outside London there are two local government systems which make up LPAs. In certain parts of the country, a two tier system applies where local government comprises County Councils under which several District Councils are responsible for planning smaller constituent areas. In other areas a single level of Unitary Authorities is responsible for all local government functions. Although LPAs are responsible for planning decisions, national government also has the right to intervene where there is reason to believe a LPA has not followed local or national policy.

Sections 70 and 106 of the Act are of particular relevance when considering Travel Plans. Section 70 of the Act gives LPAs the power to impose Planning Conditions on a development. Such conditions require a developer to put something related to their development into place either before or at a defined time after a develop- ment has opened. Section 106 allows LPAs to negotiate legally binding contributions, arrangements or restrictions in relation to a new development. These are known as Planning Obligations. Both Planning Conditions and Planning Obligations can be used to secure Travel Plans, although the Planning Obligation is preferred due to its flexibility in terms of wording and enforcement options. Implications of the use of the two planning mechanisms are well covered by other literature (e.g. Rye et al. 2011).

The Planning and Compulsory Purchase Act 2004 amended several parts of the Town and Country Planning Act with a view to speeding up the planning process. One of the key reforms was streamlining of the spatial planning system. The Act saw the replacement of the previous system of unitary, local and structure development plans being replaced by Regional Spatial Strategies (RSS) and Local Development Frameworks (LDF) prepared by LPAs. However, with the aim of increasing the powers of local government and communities in planning policy and decision making the Localism Act (House of Commons 2011) abolished Regional Spatial Strategies, effectively reverting to a local authority spatial planning system, albeit there is an obligation to cooperate with any other parties interested in the plan. In addition, there are now opportunities to form Neighbourhood Plans at a very local level and the provision for Local Economic Partnerships.

It has been suggested (Addison 2012), the Localism Act does open up the potential for wider use of Area Travel Plans (ATPs) through Neighbourhood Plans. ATPs have been suggested as being a more effective, holistic travel demand management measure than individual site based plans, as they ensure that capacity released by an individual Travel Plan is not taken up by latent demand from elsewhere (Broadstock 2008).

\section{Planning Policy and Guidance in England}

The policy origin for Travel Plans in England was the publication of Planning Policy Guidance (PPG) 13: Transport (DoT/DoE 1994). The first version, published in 1994, required LPAs to encourage the reduction in car travel. Subsequent editions in 2001 and 2011 expanded this to include a requirement for local authorities to promote Travel Plans specifically and indeed adopt a Travel Plan themselves. The policy is quite clear on monitoring and enforcement, in that in relation to travel plans: 'They should... set out the arrangements for monitoring the progress of the plan, as well as the arrangements for enforcement, in the event the agreed objectives are not met'.

However, in 2012, following the implementation of the Localism Act, the Department revoked all PPG 13 and PPS documents, over 25 in number, and replaced them with a single National Planning Policy Framework (Department for Communities and Local Government 2012). Comprising only 60 pages, notably the NPPF is a much slimmer document; indeed reference to Travel Plans is reduced to a single clause: 'A key tool to facilitate this [sustainable transport] will be a Travel Plan. 
All developments which generate significant amounts of movement should be required to provide a Travel Plan'.

National planning policy and guidance in England is at present published by the Department of Communities and Local Government. English national guidance is currently provided by Good Practice Guidelines: Delivering Travel Plans through the Planning Process (Department for Transport 2009). Whilst the document refers heavily to the now defunct PPG, it does cover the process in great depth, including comprehensive sections on monitoring and enforcement methods. However, as the introduction to the document notes, its recommendations are: '... not additions to Government policy or law on Travel Plans'.

What is notable here is that there is now no national policy requirement for LPAs to enforce and monitor Travel Plans, only for developments to provide one. It could be argued that without a tightly worded local policy, any efforts to impose enforcement of a Travel Plan through planning obligations could increasingly be open to challenge.

In England, LPAs have always been required to produce their own local policies and under the Localism Act this obligation is stronger than ever, as implied above.

\subsection{Scotland}

\section{Planning Law in Scotland}

In Scotland, planning law is defined by the Scottish Government. The principal legislation in force is the Town and Country Planning (Scotland) Act (House of Commons 1997) and the Planning etc. (Scotland) Act (Scottish Parliament 2006).

The Town and Country Planning (Scotland) Act contains similar provisions to its English counterpart of 1990. Section 1 of the Act defines the planning authority responsible as the local authority for that geographical area. Unlike England, all local authorities in Scotland are unitary authorities, of which there are 32 in total.

Section 41 of the Act gives local authorities in Scotland the power to attach Planning Conditions to a development consent. Similarly, Section 75 of the Act gives local authorities the powers to enter into a legal agreement with a person in connection with the development of land. Such a mechanism is again known as a Planning Obligation.

In essence, although through different legislation, the powers granted to local authorities in Scotland are equivalent to those of their counterpart LPAs in England, with Planning Conditions and Planning Obligations being the key mechanisms for securing Travel Plans.

Like the two tier English areas, historically Scotland operated on a system of Structure Plans and Local Plans. Structure Plans were long term development plans covering a wide area. There were 17 Structure Plan areas in total. Local Plans then guided the delivery of development at a local level. Each of the 32 local authorities was required to produce a plan which supported the Structure Plan.
The Planning etc. (Scotland) Act 2006 amended this system. Each of the 32 local authorities is still required to produce a plan, now known as a Local Development Plan. However, only the local authorities in and around Scotland's four main city areas are required to work together to produce a joint plan, known as a Strategic Development Plan. In Scotland therefore, planning between authorities (at least in and around major population centres) is required, whereas in England there is only 'an obligation to cooperate'.

\section{Planning Policy and Guidance in Scotland}

National planning policy in Scotland is published by the Scottish Government (formerly the Scottish Executive). Guidance is also published by its transport agency responsible for national transport infrastructure, Transport Scotland.

Travel Plans (or at the time, Green Transport Plans) were first included within Scottish policy with the publication of National Planning Policy Guideline (NPPG) 17 (Scottish Executive 1999). The later version of the document in support of the National Planning Framework was known as Scottish Planning Policy (SPP) 17 (Scottish Executive 2005). The policy had a clear statement for the agreement, implementation and enforcement of Travel Plans: 'Travel Plans associated with a planning permission should be specified through a planning agreement, negotiated with the developer, in order that they may be adequately implemented and enforced'.

SPP 17 formed part of a suite of planning policy documents. However, as in England, in 2010 the Scottish Government consolidated these documents into a single, streamlined policy simply titled Scottish Planning Policy (SPP) (Scottish Government 2010).

SPP essentially devolves policy responsibility on Travel Plans to the local authority for inclusion in its own plan or policy: 'Development plans or supplementary guidance should explain when a Travel Plan will be required in support of an application for planning permission'.

At the time of writing, a revised SPP was being prepared by the Scottish Government. Interestingly, whilst being generally supportive of travel by more sustainable modes, the Consultation Draft of the document (Scottish Government 2013) makes no reference whatsoever to Travel Plans.

Despite the omission of Travel Plans from emerging policy, guidance on their implementation continues to be given in Transport Assessment Guidance (Transport Scotland 2012), an update on previous national Travel Plan advice (Transport Scotland 2005). The document is clearer on the role of Travel Plans, in that: 'All applications meeting the threshold for a Transport Assessment may require a Travel Plan although it should be realised that developments below the threshold may nevertheless contribute to sustainable travel'.

Guidance is also available at a local level which is reviewed in the desktop study as part of this work. 


\subsection{Other Drivers for Travel Plan Delivery in the UK}

BREEAM $^{\oplus}$ (http://www.breeam.org) is a standard for best practice in sustainable building design and includes a number of transport related requirements. One of the requirements, TRA 05, specifies provision of a Travel Plan. Credits can be awarded to a building if it can be shown that an up-to-date Travel Plan is being applied to all building users. Compliance with BREAAM $^{\odot}$ may make the building more marketable to future occupiers, thus representing a non-planning related incentive for the development and implementation of Travel Plans.

Specific programmes to target travel behaviour, such as the Choose Another Way programme in Scotland, mirror similar approaches in England (such as Ways to Work) in that they provide some additional national resources devoted to travel planning. However, although important, these are directed at business Travel Plans outside of the planning process and their detailed consideration and comparison is beyond the scope of this paper.

\subsection{Summary}

Ultimately in both England and Scotland the onus of implementation of Travel Plans is the local authority. The most recent legislation and guidance in both countries is increasing this responsibility, and arguably the freedom with which it may be achieved. The Scottish guidance, however, is notable in aligning travel planning more closely with Transport Assessment guidance, whereas in England the two areas of transport planning are guided by the aims of their individual publications. This potentially leads to a focus on travel planning only where
Transport Assessments are required, thus diminishing its role in smaller developments with minimal car traffic impacts, and positioning travel planning as a tool to assist the forecasting of a development's impacts, rather than in its long term management. A summary of provision is given in Table 2.

The remainder of this paper looks at the comparative positions of the two countries at the sharp end of delivery, and questions whether within this legal and policy framework it is functioning correctly.

\section{Previous Studies in England and Scotland}

\subsection{England}

The first study to be considered was the work undertaken by GORS/DfT (2007). The work looked in general at the uptake of smarter choices measures by LPAs in England, but makes specific reference to Workplace Travel Plans. The study reviewed 82 Local Transport Plans (LTP) and categorised the content of the LTP with reference to the measure in question as having: 'no reference, minimal reference, reasonable reference or significant reference, the latter two meaning that the LPA was noted as proactive, with actions and targets in place.

The research found that all LTPs surveyed made at least some reference to Travel Plans. Around two thirds of these made reasonable or significant reference. Twenty six of the local authorities surveyed stated that they had a full or part Travel Plan officer in post. However, only nine of the authorities surveyed were able to provide evidence of the measured impact of Travel Plans, despite most of the local authorities having targets set.

Table 2. Comparison of current Scottish and English provision for Travel Plans

\begin{tabular}{|c|c|c|}
\hline & Scotland & England \\
\hline \multicolumn{3}{|c|}{ Responsible agencies } \\
\hline Local & Local unitary authorities & $\begin{array}{l}\text { Local planning (district and unitary) and } \\
\text { transport authorities }\end{array}$ \\
\hline National & Transport Scotland & Department for Transport \\
\hline \multicolumn{3}{|c|}{ Local policy tools } \\
\hline Land use planning & $\begin{array}{l}\text { Local Development Plan; } \\
\text { Strategic Development Plan }\end{array}$ & Local Plan \\
\hline Transport & Local Transport Strategy & Local Transport Plan \\
\hline Supplementary guidance & Supplementary Planning Guidance & Supplementary Planning Document \\
\hline \multicolumn{3}{|c|}{ National legislation } \\
\hline Land use planning & $\begin{array}{l}\text { Section } 75 \text { of the Town and Country Planning } \\
\text { (Scotland) Act } 1997 \text { and the Planning [etc.] } \\
\text { (Scotland) Act } 2006\end{array}$ & $\begin{array}{l}\text { Sections } 70 \text { and } 106 \text { of the Town and Country } \\
\text { Planning Act } 1990 \text { and the Planning and } \\
\text { Compulsory Purchase Act } 2004\end{array}$ \\
\hline Transport & $\begin{array}{l}\text { Roads (Scotland) Act } 1984 \text { (House } \\
\text { of Commons 1984) }\end{array}$ & Highways Act 1980 (House of Commons 1980) \\
\hline \multicolumn{3}{|c|}{ National policy and strategy } \\
\hline Land use planning & Scottish Planning Policy & National Planning Policy Framework \\
\hline Transport & National Transport Strategy & Various \\
\hline \multicolumn{3}{|c|}{ National guidance } \\
\hline Travel Plans & Transport Assessment Guidance & $\begin{array}{l}\text { Good Practice Guidelines: Delivering Travel } \\
\text { Plans through the Planning Process }\end{array}$ \\
\hline
\end{tabular}


This would seem to imply that the monitoring and enforcement of Travel Plans was not as prevalent as hoped.

Work by Young (2006) reported in Rye et al. (2011) surveyed 139 LPAs and achieved a $62 \%$ response rate. It showed that on average 40 Travel Plans had been secured by each LPA, with $75 \%$ secured through the planning process. The work notes that PPG 13 was the main enabler of this approach, with a minority of authorities using their own local guidance.

The work also notes that planning conditions, rather than obligations, tended to be the preferred means of securing a Travel Plan. In terms of monitoring over $40 \%$ of authorities stated they did not monitor or could not identify how they monitored Travel Plans. Where enforcement was concerned, over $30 \%$ of authorities admitted awareness of breach of conditions with regard to Travel Plans, with many other authorities choosing not to answer the question.

Finally work by Lewis (2009) undertook a smaller scale but more detailed interview survey of local authorities. The work is useful in understanding the reasons behind some of the findings of the previous two studies.

Reflected again through this research was a reliance on national standards (PPG 13) or guidance (Department for Transport 2009) to define the requirements for a Travel Plan in association with a development. Lewis (2009) also notes it is the developer's consultants, rather than the LPA, that drives the thresholds for Travel Plans, often using their experience from precedents elsewhere. This does highlight a disadvantage in the localised approach, in that if a local authority chooses its own specific policy, it may be difficult to defend against other (potentially neighbouring) authorities' approaches.

On monitoring and enforcement of Travel Plans, Lewis (2009) makes an interesting observation in that it often only takes place where there is a specific transport issue of concern. For example, if parking were an issue in association with a development, then this was likely to generate a monitoring regime. However, if the Travel Plan was solely associated with general travel demand, then monitoring and enforcement was highly unlikely; in fact some of Lewis' respondents perceived 'encouragement' alone of Travel Plans as being sufficient to discharge the LPA's duties.

\subsection{Scotland}

The most significant piece of research on Travel Plans in Scotland found was by the Scottish Executive (2006a). It found that the key barriers to Travel Plan implementation in Scotland were resourcing, limited awareness, lack of incentives and monitoring. It recommended better national guidance and more coordination of activity, in addition to increased funding for dedicated resources.

\section{Current Practice in Scotland}

\subsection{Desktop Study}

To determine to what degree the implementation of Travel Plans has been progressed, a trawl of a selection of Scottish local authorities' Local Development Plans and Local Transport Strategies was undertaken, in an approach similar to that undertaken by GORS/DfT (2007) for England. This informed the questions asked in the online survey.

There is clearly variation under the current Scottish policies and legislation, with examples of both strong and weak approaches to travel planning. These range from authorities with their own Supplementary Planning Guidance (e.g. Falkirk Council 2012) resembling best practice English authorities (e.g. Somerset County Council 2011) and those with specific travel planning policies within Local Development Plans and Local Transport Strategies (e.g. Aberdeenshire Council 2012), to those with guidance notes, and those towards the other end of the scale where there is very little, if any, observable references to travel planning in local policy or guidance documents.

\subsection{Online Survey Results}

At the close of the online survey, a total of 22 responses from the 32 local authorities in Scotland had been received. This represents a response rate of $69 \%$. This figure is very similar to that achieved by the work of Young (2006) in England and is likely to be a comparable and representative sample.

\section{The Use of Travel Plans}

The use of Travel Plans in association with development was universal across all local authorities; every authority stated or agreed with the statement they used them as a travel demand management tool. When asked how many Travel Plans were required during an average year, the answer varied, presumably depending on population and current rate of development. Assuming a normal distribution of responses, the results suggest a typical local authority in Scotland deals with between 12 and 15 new Travel Plans every year. The use of Travel Plans did vary with development type, as shown in Fig. 1.

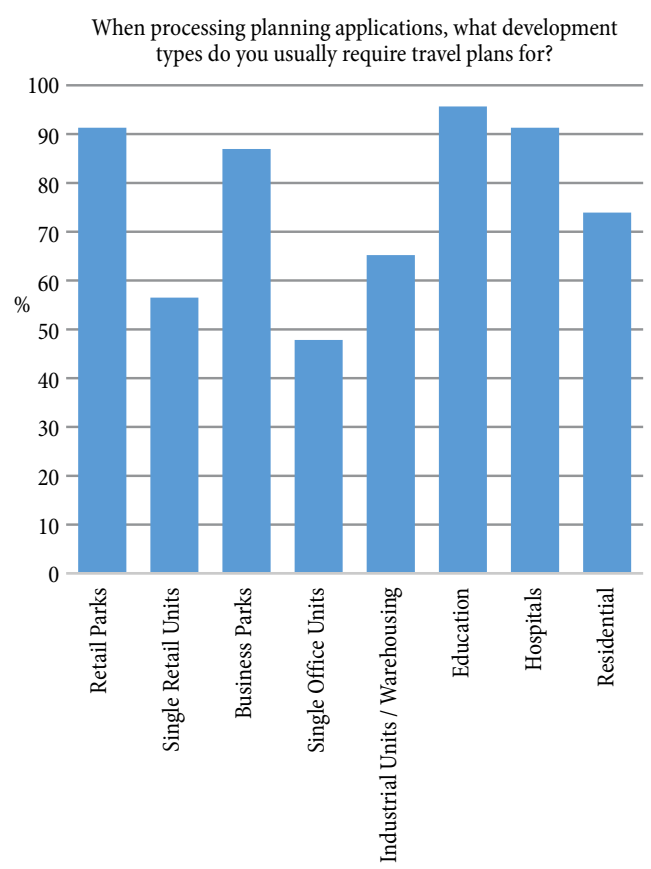

Fig. 1. Development types for Travel Plans 
Perhaps unsurprisingly given government policy on schools, virtually all local authorities required Travel Plans in association with educational land uses. Major employers such as retail/business parks and hospitals also had a strong requirement. There was a reduced requirement for Travel Plans in relation to smaller developments such as single retail and office units. This result could perhaps suggest the benefits of area Travel Plans in capturing smaller trip attractors.

\section{Planning and Legal Implications}

Respondents were asked about their choice of planning conditions and planning obligations when securing Travel Plan measures. Over 50\% of respondents said that they always or in most cases used planning conditions. Planning obligations were less frequently used, although only $13 \%$ stated that they had never used them.

When asked their views on the current legislation for securing Travel Plans, respondents said that in general conditions were chosen because they were easier and were preferred by developers. Some felt that the legislation did not allow for enforcement of Travel Plans. One local authority believed that Section 75 agreements were deemed to be complex to set up and one suggestion for improvement was that a standard model agreement be developed for use by all local authorities (already used by some single authorities). The involvement of solicitors and legal teams added to the burden on resources, hence the route of conditions was often chosen instead.

The lack of implementation and enforcement was felt by many to undermine the credibility of Travel Plans in general. It was suggested by one respondent that Travel Plans should only be a requirement if there was real commitment from all parties to make them work.

\section{Scottish Government Policy}

On current Scottish Government policy, the response was generally a positive one. Over $40 \%$ of respondents either agreed or strongly agreed that policy was clear on the role of Travel Plans. Some 45\% were neutral on the issue, with only $15 \%$ believing policy was not clear. However, one respondent commented that whilst awareness of the benefits of Travel Plans were widely known in the transport planning profession (as reflected by policy), the issues occurred mostly in the execution of them.

Building on this issue, a respondent noted that SPPs have now been significantly reduced in size. Whilst this has some benefits it was noted that transport issues, in particular Travel Plans, now appear to be a much less significant issue in determining an application. Furthermore, a key issue identified was the lack of national thresholds achieving consistency across local authorities. An example was provided where a developer had been faced with some stringent Travel Plan and parking measures in one location, and claimed to have taken the decision to relocate to a neighbouring authority where conditions were less onerous.

\section{Scottish Government Guidance}

The response on current Scottish Government Guidance on Travel Plans was also a positive one. Nearly $60 \%$ of respondents agreed that documents such as the Transport Assessment Guidance (Transport Scotland 2012) were helpful in defining and promoting the use of Travel Plans. 27\% of respondents were neutral and 13\% disagreed.

Despite a positive view on the Scottish Government guidance, several local authorities chose to use their own. There was some feeling that the national guidance represented a 'one size fits all' approach; others were not aware that a new version had been published.

\section{Local Authority Policy and Practice}

Table 3 shows the support for Travel Plans in the current policies of the local authorities that responded to the survey. In addition to the policies shown, one local authority stated that it was developing a detailed guidance document on Travel Plans. Another stated that their local roads standards contained sections on Travel Planning.

Whilst Travel Plans in general appear to be present in many local authorities' policies, there appeared to be some issues in implementation of these policies. Scepticism was noted at senior officer and councillor level with regard to the benefits. Whilst many authorities appeared to support the principle, when implementation was considered they were often considered as 'tick box exercises' which were seldom followed through.

\section{Monitoring}

Fig. 2 shows the resourcing provision across the local authorities surveyed. Exactly one third of local authorities reported having a dedicated Travel Plan officer, either in a full time capacity, part time, or shared with another role.

Table 3. Local authority policy and guidance for Travel Plans

\begin{tabular}{lcccc}
\hline & $\begin{array}{c}\text { Already } \\
\text { supports } \\
\text { Travel Plans }\end{array}$ & $\begin{array}{c}\text { Does not support Travel Plans } \\
\text { at present but will in future }\end{array}$ & $\begin{array}{c}\text { No intention for } \\
\text { document to support } \\
\text { Travel Plans }\end{array}$ & $\begin{array}{c}\text { Not sure / Don't } \\
\text { know }\end{array}$ \\
\hline Local Transport Strategy & $70 \%$ & $5 \%$ & $5 \%$ & $20 \%$ \\
\hline $\begin{array}{l}\text { Local Supplementary } \\
\text { Planning Guidance }\end{array}$ & $85 \%$ & $0 \%$ & $5 \%$ & $10 \%$ \\
\hline $\begin{array}{l}\text { Informal Council } \\
\text { Guidance Document }\end{array}$ & $47 \%$ & $0 \%$ & $16 \%$ & $37 \%$ \\
\hline Local Development Plan & $38 \%$ & $6 \%$ & $18 \%$ & $38 \%$ \\
\hline
\end{tabular}




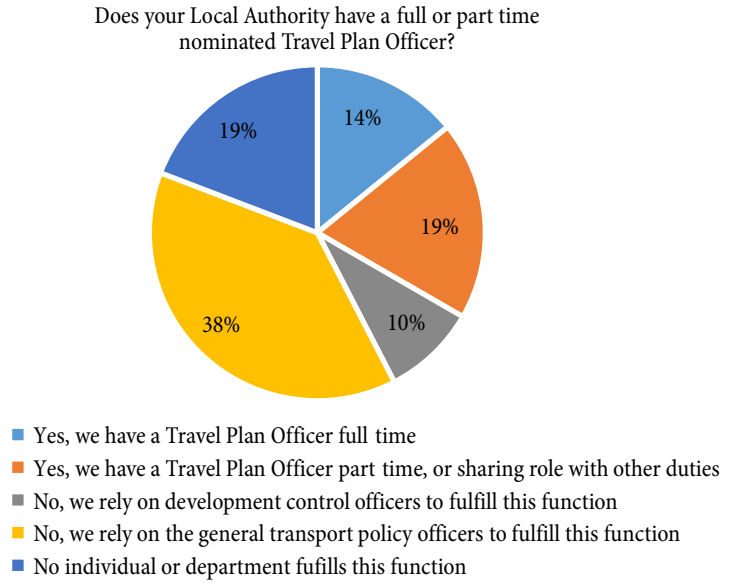

Fig. 2. Local authority resourcing

$19 \%$ of authorities had no individual fulfilling this function, with the remainder of authorities relying on other transportation officers to undertake the role.

An important fact revealed by the survey was that whilst many of the local authorities had formally titled Travel Plan officers, in many cases the responsibility of the individual concerned school Travel Plans only. Some officers did undertake additional work with regard to workplace Travel Plans, but this was not necessarily their main duty.

The authorities were also questioned on the monitoring regimes they adopted. With regard to the specific actions or measures proposed within Travel Plans, just under $25 \%$ of authorities either 'always' or 'in most cases' monitored implementation. 19\% of authorities claimed never to verify actions had been carried out. More starkly, when asked about targets and trip reductions, nearly $40 \%$ of authorities stated that they never check the achievements of Travel Plans in this regard. No single authority could show that they monitored every Travel Plan they agreed to. When Travel Plans are monitored, the vast majority are only monitored for the first five years, after which interest appears to fall away very rapidly.

\section{Enforcement}

Given the lack of monitoring, perhaps unsurprisingly awareness of breaches of legal agreements was low amongst respondents. 79\% said that they were aware of no breaches of Travel Plan legal agreements. The remainder stated that they were aware of up to ten agreements which to their knowledge had been breached. Of these breaches, only two local authorities could cite examples of where the breach had been remedied. The reasons given for the lack of enforcement of Travel Plan agreements is shown in Fig. 3.

Lack of resources was cited by most local authorities as being one of the reasons for lack of enforcement. Most of the other reasons were far less significant in the responses given in the survey. However, as one of

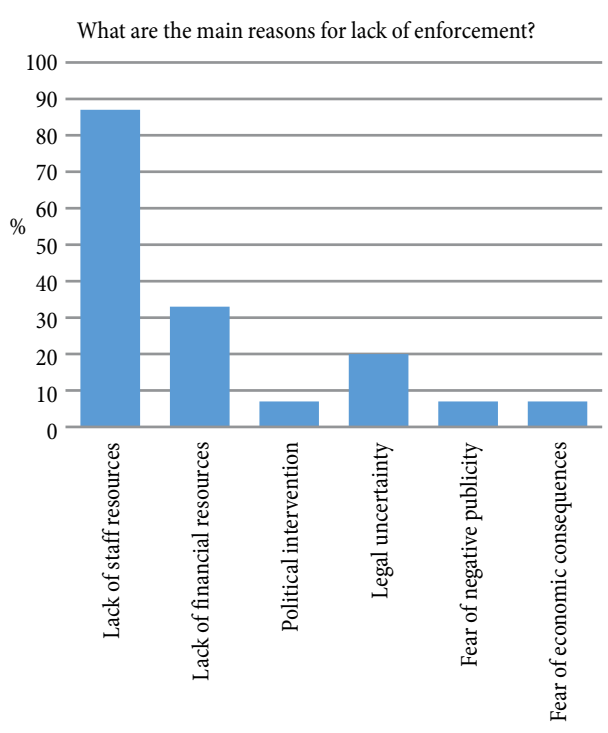

Fig. 3. Reasons for lack of enforcement

the local authorities pointed out, if so little monitoring is done (as suggested here) then it is unlikely than any other barrier would be immediately apparent. There was some evidence to suggest that if monitoring were done, then there may well be a political reluctance to undertake enforcement given the absence of senior officer and councillor support.

\section{Future for Travel Plans}

The final part of the survey looked at respondents' views on what they believed would happen to Travel Plans in Scotland in future. Just over half of the respondents saw their use as a transport demand management measure staying about the same. Around a third of respondents saw their usage increasing, with only $15 \%$ stating they believed use would decline.

Several suggestions were given with regard to improving the effectiveness of Travel Plans implementation in Scotland. Improved resourcing was a key issue, but also a shift in focus from enforcement to working with companies to illustrate other benefits. Respondents also suggested being more selective about applications, in particular only committing to Travel Plans where all parties can deliver, moving away from a 'box ticking' exercise.

Stronger leadership and commitment was seen as a key issue. Suggestions were made with regard to strengthening of Section 75 agreements and reducing the right of appeal. A key weakness in the process at the moment was the lack of support from councillors and senior officers. It was suggested that national government should take the lead here and reinforce the importance of Travel Plans in the planning process. This would seem, however, to be moving in the opposite direction to government policy, which appears to be being less specific and prescriptive, as now discussed. 


\section{Discussion}

At the beginning of this paper (Section 1.1), three questions were posed:

What is the current comparative position of Travel Plans as a transport demand management tool in Scotland and England?

Over the past few years in England, it appears that Travel Plans have plateaued in effectiveness. Adoption is generally now fairly widespread, but a critical lack of monitoring and enforcement appears to be compromising their ability to further influence travel demand. Scotland started from a lower base than England, and adoption has been more gradual. The figures obtained in this study suggest that an average Scottish authority deals with roughly half the number of Travel Plans per year compared to English counterparts. This could, however, be associated with issues concerned with the size of authority area and rate of economic development; such factors were beyond the scope of this study. There is some evidence to suggest that in Scotland, Travel Plans are promoted more in association with larger developments and less so for individual units. The introduction of more Area Travel Plan (ATP) activity may go some way to improving uptake in such circumstances.

To what degree does the different governance and legal structures in the two countries influence the success of Travel Plans?

Whilst the two countries operate different legal systems, there is no evidence to suggest that either system presents any advantage with regard to Travel Plans. The mechanism for securing Travel Plans, whilst from different Acts of Parliament, can be considered broadly interchangeable. In both countries, issues of enforcement appear to be more associated with resourcing issues, than with the law itself.

Both England and Scotland have seen substantial consolidation of planning policy in the form of NPPF and SPP respectively; in Scotland to the point where Travel Plans are no longer mentioned in the current consultative draft. This poses a real issue for both countries, as there are clear indications that authorities rely on national policy to substantiate their requirements for Travel Plans. In the absence of national standards and policy, evidence from Scotland shows that developers may start to strategically pick their sites, choosing areas where Travel Plan requirements are less onerous. Ultimately, this is likely to undermine the management of demand.

There is also an emerging difference in national government policy between the two countries which has a significant bearing on this issue. In England, the full effect of the Localism Act remains to be seen, but with regard to travel planning it implies a much stronger drive at a local level on transport policy. In this respect, each local authority is essentially responsible for its own destiny. In Scotland, at least in the city-region areas, there still remains an element of coordination between authorities through the Strategic Development Plan exercise and the ongoing presence of Regional Transport
Partnerships. This may see some of the issues with regard to differing policies between local areas reduced, although it should be noted that the early adoption of Local Development Plans may limit the degree of this influence.

What is the likely future of Travel Plans in the two countries and what lessons can be learnt for adoption of Travel Plans by other nations?

The big issue that has been highlighted by this work is that the depth of national government policy in both countries is diverging from the stated needs of local authorities. The feedback from this work and much of the published work in England suggested that authorities value the national government policy and desire more, rather than less leadership from national government. This applies particularly with regard to generating support from councillors and senior officials.

In England, the Localism Act could be seen equally as an opportunity or a threat to Travel Plans. On the negative side, the lack of national government leadership could result in a vacuum of empty policy which is never followed through. Taking a more positive view, with strong local leadership and belief, the Act could revitalise Travel Plans by opening up new opportunities, for example the prevalence of Area Travel Plans.

Regardless of the outcome, other nations looking at Travel Plans are recommended to look closely at their existing structures of government to see what works best for them, aligning their policy on Travel Plans accordingly.

\section{Concluding Remarks}

At the national level, there appears to be little difference between the legislative framework for Travel Plans in England and Scotland. Both appear to consolidating transport policy, with a resulting loss-of-focus on Travel Plans unless they are required by the local authority. A key emerging difference however is the NPPF in England and the localism agenda, which have brought about many changes. Whist this paper updates the view in Scotland further work is recommended once the Localism Act has fully embedded, to ascertain its effect on Travel Plans.

However, is this really a debate between big governments and localism, or around the role and culture of the development industry in fulfilling the role of development enabler and behaviour change agent otherwise, elsewhere and historically funded and provided by public sector bodies? It is easy to suggest that the success or failure of Travel Plans rests with the quality of leadership, either at a local or a national level. However, it could be argued that this is the wrong question to ask.

Many of the respondents to this survey suggested that there was too much focus on enforcement (or the lack of it) and that the real role of government, local or national, lies with educating and supporting organisations to achieve the benefits. However, it could be argued that in focusing so much on the stick, both countries have in fact lost sight of the carrot. 
Given the emerging differences in policy within the constituent parts of UK, future work could usefully review progress within each jurisdiction as time progresses. Comparison with international benchmarks, with both mature and emerging adopters of Travel Planning would also further build on the work undertaken here.

\section{Acknowledgements}

The authors would like to thank all local authority officers who took the time to answer the survey.

\section{References}

A New Deal for Transport: Better for Everyone. 1998. Department for Transport. London, UK. Available from Internet: http://webarchive.nationalarchives.gov.uk/+/http://www. dft.gov.uk/about/strategy/whitepapers/previous/anewdealfortransportbetterfo5695

Aberdeenshire Council. 2012. Local Transport Strategy. Aberdeen, UK. 30 p. Available from Internet: http://www.aberdeenshire.gov.uk/transportation/lts/2012FinalLTS.pdf

Addison, L. 2012. Travel plans and the national planning policy framework, in Proceedings of the 23 rd Annual TRICS ${ }^{\infty}$ Transport \& Development Conference, 8 November 2012, London, UK.

Broadstock, D. C. 2008. Area travel plans v's local travel plans, Traffic Engineering and Control 49(2): 64-68.

Department for Communities and Local Government. 2012. National Planning Policy Framework. London, UK. 65 p. Available from Internet: https://www.gov.uk/ government/uploads/system/uploads/attachment_data/ file/6077/2116950.pdf

Department for Transport. 2009. Good Practice Guidelines: Delivering Travel Plans through the Planning Process. London, UK. DfT Publications. 153 p.

DoT/DoE. 1994. Planning Policy Guidance 13: Transport. Department of Transport (DoT), Department of the Environment (DoE), London.

Enoch, M.; Ison, S. 2010. Travel plans: a way forward?, Proceedings of the ICE - Urban Design and Planning 166(2): 126-135. http://dx.doi.org/10.1680/udap.10.00042

Enoch, M. 2012. Revisiting the future of travel planning, Traffic Engineering and Control 53(8): 287-297.

Falkirk Council. 2012. Travel Plans: Supplementary Planning Guidance Note. Scotland. 20 p. Available from Internet: http://www.falkirk.gov.uk/services/development/planning/ planning_and_environment/supplementary_planning_ guidance/PDFs/travel_plan_spg.pdf

GORS/DfT. 2007. Review of the Take-up of Smarter Choices in Local Transport Plans. Government Operational Research Service (GORS), Department for Transport (DfT), London, UK.

Hendricks, S. J. 2008. Four challenges to incorporating transportation demand management into the land development process, Transportation Research Record 2046: 30-36. http://dx.doi.org/10.3141/2046-04

House of Commons. 2011. Localism Act 2011. HMSO. London. Available from Internet: http://www.legislation.gov.uk/ukpga/2011/20/contents/enacted

House of Commons. 2004. Planning and Compulsory Purchase Act 2004. HMSO. London. Available from Internet: http:// www.legislation.gov.uk/ukpga/2004/5/contents
House of Commons. 1998. Scotland Act 1998. HMSO. London. Available from Internet: http://www.legislation.gov.uk/ukpga/1998/46/contents

House of Commons. 1997. Town and Country Planning (Scotland) Act 1997. HMSO. London. Available from Internet: http://www.legislation.gov.uk/ukpga/1997/8/contents

House of Commons. 1990. Town and Country Planning Act 1990. HMSO. London. Available from Internet: http:// www.legislation.gov.uk/ukpga/1990/8/contents

House of Commons. 1984. Roads (Scotland) Act 1984. HMSO. London. Available from Internet: http://www.legislation. gov.uk/ukpga/1984/54/contents

House of Commons. 1980. Highways Act 1980. HMSO. London. Available from Internet: http://www.legislation.gov. uk/ukpga/1980/66

Lewis, D. 2009. Is the Planning Process Being Used Effectively to Secure Travel Plans? Unpublished MSc Dissertation, Edinburgh Napier University, Edinburgh.

OECD. 2013. OECD Economic Outlook. Vol. 2013/1. OECD Publishing. http://dx.doi.org/10.1787/eco_outlook-v2013-1-en

Pushkova, D. 2010. Muscovites Hopeful New Mayor Can Win War Against Traffic Jams. Russia. Available from Internet: http://rt.com/news/moscow-traffic-jams-war

Replogle, M.; Kondransky, M; Daizong, L; Liu, Y.; Wen, W. Y.; Weinberger, R.; Kaehny, J.; Rufo, M.; Creutzig, F. 2009. Travel Demand Management in Beijing: Opportunities for Green, High-Tech, Equitable Transport. Prepared by Institute for Transportation and Development Policy and the China Sustainable Energy Program, The Energy Foundation. 47 p.

Roby, H. 2010. Workplace travel plans: past, present and future, Journal of Transport Geography 18(1): 23-30. http://dx.doi.org/10.1016/j.jtrangeo.2008.11.010

Rye, T.; Green, C.; Young, E.; Ison, S. 2011. Using the land-use planning process to secure travel plans: an assessment of progress in England to date, Journal of Transport Geography 19(2): 235-243.

http://dx.doi.org/10.1016/j.jtrangeo.2010.05.002

Scottish Executive. 2006a. The Provision of Travel Plans: Mapping Activity in Scotland. Edinburgh. 93 p. Available from Internet: http://www.scotland.gov.uk/Publications/2006/06/16100731/0

Scottish Executive. 2006b. Scotland's National Transport Strategy. Edinburgh. 86 p. Available from Internet: http://www. scotland.gov.uk/Publications/2006/12/04104414/0

Scottish Executive. 2005. Scottish Planning Policy (SPP) 17: Transport and Planning. Edinburgh. 30 p. Available from Internet: http://www.scotland.gov.uk/publications/2005/08/16154406/44078

Scottish Executive. 1999. National Planning Policy Guidance (NPPG) 17: Transport and Planning. Edinburgh. Available from Internet: http://www.scotland.gov.uk/Publications/1999/04/nppg17

Scottish Executive. 1998. Scottish Integrated Transport White Paper, Travel Choices for Scotland. Edinburgh.

Scottish Government. 2013. Scottish Planning Policy: Consultation Draft. 69 p. Edinburgh. Available from Internet: http:// www.scotland.gov.uk/Resource/0042/00421076.pdf

Scottish Government. 2010. Scottish Planning Policy. Edinburgh. Available from Internet: http://www.scotland.gov.uk

Scottish Parliament. 2006. Planning etc. (Scotland) Act 2006. Edinburgh. Available from Internet: http://www.legislation. gov.uk/asp/2006/17/contents 
Scottish Parliament. 2005. Transport (Scotland) Act 2005. Edinburgh. Available from Internet: http://www.legislation.gov. uk/asp/2005/12/contents

Somerset County Council. 2011. Travel Planning Guidance. Taunton. 158 p. Available from Internet: http://www.somerset.gov.uk/policies-and-plans/strategies/transport-strategy

Strompen, F.; Litman, T.; Bongardt, D. 2012. Reducing Carbon Emissions through Transport Demand Management Strategies: a review of International Examples. Final Report. Beijing Transportation Research Center (BTRC), Beijing. 132 p. Available from Internet: http://tdm-beijing.org/files/ International_Review.pdf

Transport Scotland. 2005. Guide to Transport Assessment in Scotland. Glasgow, Scotland.

Transport Scotland. 2012. Transport Assessment Guidance. Glasgow, Scotland. 57 p. Available from Internet: http:// www.transportscotland.gov.uk/files/documents/analysis/ Planning_Reform_-_DPMTAG_-_Development_Management__DPMTAG_Ref__17____Transport_Assessment_ Guidance_FINAL_-_June_2012.pdf

Tricker, R. C. 2008. Integrating Travel Planning with the UK Sustainable Development Strategy. Paper presented at the Transport Practitioners' Meeting, Reading, July 15, 2008.

UK Parliament. 1707. Act of Union 1707. Available from Internet: http://www.parliament.uk/about/living-heritage/evolutionofparliament/legislativescrutiny/act-of-union-1707

Young, E. 2006. Does Using the Planning Process Work as a Means of Securing Effective Travel Plans?: Unpublished MSc Dissertation, Edinburgh Napier University, Edinburgh. 